\title{
ИЗ ИСТОРИИ СОЗДАНИЯ МИНУСИНСКОГО МУЗЕЯ ИМЕНИ Н.М. МАРТЬЯНОВА
}

В статье поднимается вопрос об истории становления музея в г. Минусинске. Рассмотрена специфика деятельности музея в первые годы своего существования. Проведен анализ взаимодействия музея с местными органами власти. Данная статья будет интересна специалистам в области музеологии, истории Сибири и краеведения.

Ключевые слова: музей, Минусинск, история, краеведение, Н.М. Мартьянов.

\section{FROM HISTORY OF CREATION OF THE MINUSINSK MUSEUM NAME N.M. MARTYANOV}

The article touches upon question about history of becoming first museum in the city of Minusinsk. It was considered the specificity of work museum during first years. The author repots on positive interaction 
between museum and local authorities. Particular attention was paid to research activity of N.M. Martyanov and his an exceptional role in creating of museum. Besides the author attracts attention to significant efforts of private individuals in further museum's development and extension of his collections. It is analyzed the work of museum with local institutions and interaction with patrons of Eastern Siberia. It was noted museum influence on formation and development interests of Minusinsk citizens in the area of history of own region and his natural features.

Keywords: museum, Minusinsk, history, local history, N.M. Martyanov.

Одним из первых музеев Восточной Сибири стал Минусинский музей, открывшийся в 1877 г. Основателем музея стал краевед Н.М. Мартьянов, который был приглашен на 3 года в город на должность управляющего вольной аптекой. Н.М. Мартьянов увлекался собиранием ботанических и минералогических коллекций, а также археологией. Переезд в Минусинск стал для него возможностью продолжения исследовательской деятельности. Накопленные материалы Н.М. Мартьянова составляли около 2000 предметов, которые в скором времени он стал дарить: часть коллекций научным учреждениям России и Германии, а также Минусинскому училищу, в котором они использовались в качестве наглядных педагогических материалов [1, с. 12].

Появления местных музеев России во второй половине XIX в. было явлением времени. Эта идея, которую продвигал директор Петербургского педагогического музея В. Коховский, получала все большую поддержку в регионах. По мнению Ф.Я. Кона, собирательская деятельность Н.М. Мартьянова стала одним из фракторов роста музея [2, с. 6]. Вторым фактором стала местность, на которой появился музей. Минусинская котловина представляла значительные возможности для научного изучения хакасских древностей. Сам Мартьянов в своих воспоминаниях пишет, о том, «что Минусинское общество сочувственно отнеслось к идее основания музея» [2, с. 46].

Значительный объем материалов позволяет говорить об исключительной роли Н.М. Мартьянова в его создании. Но, по мнению Ф.Я. Кона, необходимо отметить всех людей, стоявших у истоков музея. Сам Мартьянов в своих письмах к родным писал, что находил людей из числа местных жителей, заинтересованных в научном изучение древностей. На собранные им коллекции они смотрели не как на диковину, а как на достойный материал, который необходимо изучать [2, с. 36].

В 1877 г. Н.М. Мартьянов подает прошение в Городскую Думу о создание музея в городе. В нем прописываются основные критерии создания музея, количество собранных материалов, отмечены возможные благотворители. На основании прошения Н.М. Мартьянова Городская Дума постановила создать музей под названием «Минусинский Местный Публичный Музей», и избрала комиссию для составления устава, 
в которую вошли сам Н.М. Мартьянов, А.А. Крапоткин, А.В. Малителей, а также главный руководитель и редактор устава Н. Попов.

В результате открытия музея и формирования библиотеки за счет пожертвований образовалось около 600 книг, которые по разным причинам не подходили для библиотеки. Так в 1878 г. при помощи местного общество и Городской Думы появилась общественная библиотека.

За первые 2 года деятельности музея в его фондах появилось около 4700 материалов. Естественно-исторический отдел имел 3083 предмета, антропологический 150, технический 100, предметы неизвестного происхождения 120, в библиотеке было около 2000 книг. В музеи была проведена научная обработка всех поступивших материалов. Впервые все коллекции музея были описаны и занесены в инвентарную книгу. Для удобного восприятия каждый предмет имел свою легенду, отдельно записанный как для исследователей, так и для местных жителей. Комитет музея и его хранители проделали колоссальную работу по распределению и описанию предметов. Для создания чучел животных были задействованы местные охотники и рыболовы, которые пожертвовали музею свои работы, но не в полной степени был представлен водный и наземный мир Минусинского края.

Огромные поступления в музей коллекций от частных лиц и организаций, привели к тому, что вскоре помещение музея не смогло вмещать в себе все коллекции. Так в 1885 г. И.П. Лыткин бывший в то время Городским Головой, взял на себя инициативу по постройке нового здания для музея и библиотеки. И.П. Лыткин обратился с просьбой к заводовладельцам братьям Даниловым. Вскоре они ответили положительным решением на данную просьбу и с января 1886 г. стали вносить на счет для постройки здания по 1000 р. ежегодно. И.А. Лопатин - красноярский промышленник, географ, геолог и исследователь Сибири и Дальнего Востока, после посещения г. Минусинска и музея, пожертвовал деньги для строительства. 21 февраля 1886 г. от иркутского купца И.М. Сибирякова на счет музея поступило 3000 р. Одним из условий И.М. Сибиряков стало то чтобы данное здание должно было использоваться только для задачи музея, а также должно было иметь кабинет для чтения [4, с. 3]. В мае И.М. Сибиряков увеличил свое пожертвование до 6000 р., с условием чтобы была расширена библиотека. 30 марта 1886 г. заведующий музеем подает заявление в Городскую Думу г. Минусинска, в котором были указаны денежные средства из собранных пожертвований и обоснована причина, по которой музей нуждался в новом здании. 21 апреля Городская Дума приняла решение о строительстве нового здания для музея и библиотеки, и выделило из своих средств 2000 р. [5]. Вся ответственность за сохранность денежных средств легла на Комитет Минусинского музея, в состав которого входили И.П. Лыткин, Н.М. Мартьянов, Е.Н. Зверева, Л.А. Плющ, Т.Н. Сайлотов, И.Н. Маркадин, Г.П. Сафьянов, 
И.Ф. Егорычев (был избран казначеем). Комитет постановил, что новое здание должно было быть 2-х этажным и иметь подвальный этаж, длина здания составляла около 46 м, ширина около 37 м. Стоимость постройки не должна была превысить 15000 р. [4].

В 1886 г. Д. Клеменц составил книгу в который были систематизированы научные коллекции музея, подробное описание предметов, приведен каталог и составлено описание отделов музея.

Строительство здания проходило под контролем комитета музея. После того как было определено место будущей постройки, с 4 по 17 мая 1887 г. началось копка рва для фундамента. Были проведены дополнительные исследования грунта, где проходила постройка здания музея. После строительства все образцы грунта и строительных материалов были выставлены в музее, как подтверждение надежности нового здания.

17 мая прошла церемония закладки дома. На данном событии присутствовали: комитет музея, представители города и местной школы, местные жители. На торжестве был зачитан отчет о работе музея за первые 10 лет, оглашена сумма пожертвований, которая составила 13057 р. В речи Е.Н. Зверевой и Л.А. Плюща говорилось о пользе музея и библиотеки для местных школ и жителей города. Комитет музея признал, что только благодаря пожертвованиям музей смог обзавестись новым зданием. В конце мая 1887 г. было закончено строительство цоколя, 2 июня началось строительство стен 1 этажа. На данном этапе строительства пришлось вносить коррективы в первоначальный план здания. Строительство здания заняло чуть меньше 3-х лет. В 1890 г. здание было построено полностью. Оно вмещало в себе все 5 отделов музея - это естественно-исторический, промышленный, сельскохозяйственный, антропологический, исторический (он находился в начальной стадии фрормирования коллекций) [4, с. 5].

В отчете о деятельности и состояние музея за 1890 г. Описывается то сколько единиц находилось на хранение в коллекции и сколько книг в библиотеке. Так описана вся деятельность музея за данный год. Из данного отчета можно узнать, что 20 мая 1890 г. состоялось открытие музея «в новом специально для него выстроенном, помещение - событие, которое по многим причинам должно приветствоваться как начало новой эры в жизни музея» [3, с. 1]. Открытие музея в новом здание дало ему возможность развернуть свои силы и свое значение, как образовательную, так и научную. Коллекции теперь стали не стеснены недостатком места и были выставлены полностью все для посетителей. Были оборудованы специальные комнаты для занятий ученый специалистов. Новое здание так же ало более глубокое осознание для музееведов о том, как должен выглядеть местный музей и то как правильно использовать его как площадку для общественно значимых событий. Минусинский музей 
в том виде в котором он предстал в 1890 г. смог служить пособием ученым, у которых было желание о создание своего местного музея.

На 1 января 1891 г. по каталогам музея числилось 33255 единиц хранение, которые были «так распределены по отделам:

1. Естественно-исторический отдел - 10711.

2. Антропологический - 1169.

3. Археологический -7193.

4. Промышленность - 2214

5. Сельскохозяйственный -2220

6. Нумизматический - 894

7. Образовательный (неместные предметы) - 7191.

8. Педагогический (учебные пособия) - 1589.

9. Лаборатории и рабочие кабинеты - 74» [3, с. 14].

В то время как в библиотеке в отчете за 1890 г. было куплено 13185 новых книг, на сумму 20013 р. Библиотека размещалась на 2 этаже здания музея. Ей было выделены 2 комнаты, в одной располагались книги, которые чаще всего спрашивали посетители (журналы, история, сочинения). Также было отведено 2 витрины для особо ценных и редких изданий. Эти книг не выдавались домой, с ними можно было работать только в данном зале [3, с. 24].

Уже в первые годы своего существования фонды музея увеличились в 10 раз, что свидетельствовало о заинтересованности местной интеллигенции и жителей в развитии изучения края. Несомненен вклад Н.М. Мартьянова в создания музея в Минусинске. Его научный интерес и коллекционирование местных древностей сыграло решающую роль в поддержке музея со стороны местной общественности и власти. Музей, таким образом, стал для многих исследователей и городского сообщества ориентиром в изучение географии, биологии, животного мира и истории родного края.

Ф.Я. Кон выражал мнение что Минусинский музей не только сыграл в перемене взглядов на развитие музейного сети в своем регионе, но и «то обстоятельство что он из года в год все больше и больше развивал свою деятельность, с первых годов своего существования он обратил на себя внимание учебного мира, который находил в его коллекциях немало для себя нового. Столь и общества, которое с большим удовольствие и вовлеченностью изучало новую «диковину» в своем городе. Музей и общество в течение целого ряда лет воочию убедились, что совместная работа приводит к большим результатам исследований благоприятно влияющих как на регион, так и для страны [2].

\section{Список использованной литературы и источников}

1. Минусинский публичный местный музей. Каталог и краткое описание. Томск : Типо-литография Михайлова и Макушина, 1881. 
2. Кон Ф. Я. Исторический очерк Минусинского местного музея за 25 лет (1877-1902 г.) / Ф. Я. Кон. - Казань : Тип. Императорского Университета, 1902.

3. Отчеты по Минусинскому местному музея и общественной библиотеке за 1890 год. - Минусинск : Тип. В.В. Федорова, 1891.

4. Отчет по постройке здания для Минусинского музея и библиотеки. Минусинск : Тип. В.В. Федотова, 1890.

5. Шахеров В. П. Социокультурные процессы в городской среде Байкальской Сибири XVIII - первой половине XIX в. / В. П. Шахеров. - Иркутск: Изд-во ИГУ, 2013. $-256 \mathrm{c}$.

\section{Информация об авторах}

Шахеров Вадим Петрович - профрессор, доктор исторических наук, кафедра Истории России, Исторический факультет, Иркутский государственный университет, 664025, г. Иркутск, ул. Чкалова, 2; e-mail: wodalis@yandex.ru.

Романова Анна Юрьевна - магистрант 2 года обучения, кафедра Истории России, Исторический факультет, Иркутский государственный университет, 664025, г. Иркутск, ул. Чкалова, 2; e-mail: madam.romanowa-a@yandex.ru.

\section{Authors}

Vadim P. Shakherov - Professor, Doctor of History, Department History of Russia, History Facuity, Irkutsk State University, 2 Chkalov St., 664025, Irkutsk, Russia; e-mail: wodalis@yandex.ru

Anna Yu. Romanova - Undergraduate, the $2^{\text {nd }}$ year of Training, Department History of Russia, History Facuity, Irkutsk State University, 2 Chkalov St., 664025, Irkutsk, Russia; e-mail: madam.romaniwa-a@yandex.ru 